\title{
TINGKAT PENGETAHUAN TENTANG PEMANFAATAN BUKU KESEHATAN IBU DAN ANAK BERDASARKAN KARAKTERISTIK IBU HAMIL
}

\author{
Tri Budi Rahayu ${ }^{1}$
}

${ }^{1}$ Stikes Guna Bangsa Yogyakarta, Jln. Ring Road Utara Condongcatur Depok Sleman Yogyakarta, email: triarahayu88@gmail.com

\section{ABSTRACT}

Background : High maternal mortality rate is a problem and a concern for all countries due to the impact effect on the economy, politics and policy development. As one of the efforts to reduce maternal mortality and infant mortality rate in Indonesia, KIA book as means of integration of maternal and child health services. Lack of knowledge of pregnant women about the KIA books utilization can increase the risk of maternal and infant mortality.

Objective : This study aimed to determine the level of knowledge about the utilization of KIA book in pregnant women.

Methods : This research was descriptive quantitative with cross sectional data collection. Univariat analysis was used for the data analysis. The sampling technique was total sampling with the number of 48 pregnant women.

Results : The result of univariate analysis showed that $65 \%$ pregnant women had enough knowledge about the utilization of KIA book.

Conclusion : The level of knowledge about the utilization of KIA book is categorized into enough category.

\section{Keywords : knowledge, KIA book}

\section{PENDAHULUAN}

Tingginya Angka Kematian Ibu (AKI) merupakan masalah dan keprihatinan bagi semua negara karena dampak yang ditimbulkan berpengaruh terhadap ekonomi, politik, dan kebijakan pembangunan. AKI di Indonesia tergolong tinggi. Berdasarkan data dari Survei Demografi dan Kesehatan Indonesia (SDKI) tahun 2012, AKI berjumlah

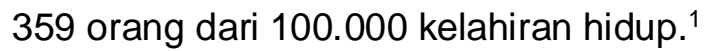

Angka kematian ibu di Provinsi Jawa Tengah masih cukup tinggi. AKI pada tahun 2012 berdasarkan laporan dari kabupaten/kota sebesar 116,34/100.000 kelahiran hidup. Angka ini mengalami peningkatan bila dibandingkan dengan AKI pada tahun 2011 sebesar 116,01/100.000 kelahiran hidup. ${ }^{2}$ Sedangkan Angka Kematian Ibu di Kabupaten Magelang pada tahun 2012 $65,47 / 100.000$ kelahiran hidup. $^{3}$

Sebagai salah satu upaya menurunkan AKI dan AKB di Indonesia, pemerintah menyusun buku KIA sebagai alat integrasi pelayanan kesehatan ibu dan anak. SK Menkes No 248/Menkes/SK/III/2004 mengenai Buku KIA memberikan dasar yang kuat untuk meningkatkan fungsi buku KIA sebagai salah satu strategi nasional dalam menurunkan $\mathrm{AKI}$ dan $\mathrm{AKB}$ melalui dana khusus dari APBN. ${ }^{4}$

Cakupan pendistribusian buku KIA di kabupaten Magelang mencapai 97,66\%. Dukungan pemerintah daerah melalui pamong kecamatan dan pamong desa sudah 
memadai, mereka telah mengadakan berbagai kegiatan untuk mendukung penggunaan buku KIA. Adapun masalah dalam pendistribusian buku KIA adalah masih adanya ibu hamil yang tidak melakukan antenatal care sehingga tidak memiliki buku $\mathrm{KIA}^{5}$

Berdasarkan hasil wawancara dalam studi pendahuluan didapatkan informasi bahwa ibu, suami, dan keluarga tidak pernah membaca buku KIA di rumah. Sehingga suami dan keluarga tidak mengetahui tanda bahaya kehamilan dan kapan harus kembali ke pelayanan kesehatan.

Di samping itu, dari 30 ibu hamil, 5 ibu hamil tidak membawa buku KIA saat melakukan pemeriksaan kehamilan, 10 ibu hamil mengaku tidak pernah membaca buku KIA ketika di rumah, dan 15 ibu hamil tidak mengetahui pemanfaatan buku KIA.

Berdasarkan latar belakang tersebut, dapat dirumuskan permasalahan yaitu "Bagaimana tingkat pengetahuan tentang pemanfaatan buku kesehatan ibu dan anak pada ibu hamil di Puskesmas Borobudur Magelang?" Tujuan dari penelitian ini adalah untuk mengetahui tingkat pengetahuan tentang pemanfaatan buku Kesehatan Ibu dan Anak pada ibu hamil di Puskesmas Borobudur Magelang.

\section{BAHAN DAN CARA PENELITIAN}

Jenis penelitian dalam penelitian ini adalah deskriptif dengan rancangan pendekatan cross sectional. Populasi dalam penelitian ini adalah semua ibu hamil yang melakukan antenatal care dan tercatat di Puskesmas Borobudur Magelang. Dalam penelitian ini teknik sampling yang digunakan adalah total sampling.

Analisa data secara univariat menggunakan statistic deskriptif untuk mendapatkan data dalam bentuk tabulasi, dengan cara memasukkan seluruh data kemudian diolah secara statistik deskriptif yang digunakan untuk melaporkan hasil dalam bentuk distribusi frekuensi dan persentase. ${ }^{6}$

\section{HASIL DAN PEMBAHASAN}

Hasil penelitian pada 48 ibu hamil menunjukkan sebagian besar responden berumur 20-35 tahun yaitu sebanyak 38 responden $(79 \%)$, pendidikan terakhir SMA yaitu sebanyak 22 responden (46\%), dan sebanyak 31 responden (65\%) merupakan ibu rumah tangga. Hasil selengkapnya dapat dilihat pada tabel berikut ini:

\section{Tabel 1. Distribusi Frekuensi Karakteristik Responden Berdasarkan Umur, Pendidikan dan Pekerjaan}

\begin{tabular}{|c|c|c|c|c|}
\hline \multirow[t]{2}{*}{ No } & \multicolumn{2}{|c|}{ Kategori Responden } & \multicolumn{2}{|c|}{ Jumlah } \\
\hline & & & $f$ & $\%$ \\
\hline \multirow[t]{4}{*}{1} & Umur & >20 tahun & 9 & 19 \\
\hline & & 20-35 tahun & 38 & 79 \\
\hline & & $<35$ tahun & 1 & 2 \\
\hline & Total & & 48 & 100 \\
\hline \multirow[t]{5}{*}{2} & Pendidikan & SD & 7 & 15 \\
\hline & & SMP & 18 & 37 \\
\hline & & SMA & 22 & 46 \\
\hline & & $\mathrm{PT}$ & 1 & 2 \\
\hline & Total & & 48 & 100 \\
\hline \multirow[t]{3}{*}{3} & Pekerjaan & $\begin{array}{l}\text { Tidak bekerja } \\
\text { Wiraswasta }\end{array}$ & 31 & 65 \\
\hline & & & 17 & 35 \\
\hline & Total & & 48 & 100 \\
\hline
\end{tabular}


Berdasarkan hasil penelitian tingkat pengetahuan tentang pemanfaatan buku KIA pada 48 responden diketahui terbanyak pada kategori cukup yaitu 31 responden (64\%) dan paling sedikit pada kategori baik yaitu 8 responden (17\%), seperti yang tercantum pada tabel berikut ini :

Tabel 2. Distribusi Frekuensi Tingkat

Pengetahuan Tentang Pemanfaatan Buku KIA

\begin{tabular}{ccc}
\hline Kategori & \multicolumn{2}{c}{ Pemanfaatan Buku KIA } \\
\cline { 2 - 3 } & $\mathbf{f}$ & $\%$ \\
\hline Baik & 8 & 17 \\
\hline Cukup & 31 & 64 \\
\hline Kurang & 9 & 19 \\
\hline Total & 48 & 100 \\
\hline
\end{tabular}

Sedangkan tingkat pengetahuan ibu

hamil tentang pemanfaatan buku Kesehatan Ibu dan Anak (KIA) berdasarkan karakteristik umur, pendidikan, dan pekerjaan, dapat dilihat pada tabel berikut ini :

Tabel 3. Tingkat Pengetahuan Ibu Hamil berdasarkan Karakteristik

\begin{tabular}{|c|c|c|c|c|c|c|c|c|c|}
\hline \multirow{2}{*}{\multicolumn{2}{|c|}{$\begin{array}{l}\text { Karakteristik } \\
\text { Responden }\end{array}$}} & \multicolumn{6}{|c|}{ Tingkat Pengetahuan } & \multicolumn{2}{|c|}{ Jumlah } \\
\hline & & \multicolumn{2}{|c|}{ Baik } & \multicolumn{2}{|c|}{ Cukup } & \multicolumn{2}{|c|}{ Krg } & \multirow[b]{2}{*}{$f$} & \multirow[b]{2}{*}{$\%$} \\
\hline & & f & $\%$ & f & $\%$ & $f$ & $\%$ & & \\
\hline \multirow[t]{4}{*}{ Umur } & $<20$ & 0 & 0 & 8 & 89 & 1 & 11 & 9 & 100 \\
\hline & $20-35$ & 8 & 21 & 22 & 58 & 8 & 21 & 38 & 100 \\
\hline & $>35$ & 0 & 0 & 1 & 100 & 0 & 0 & 1 & 100 \\
\hline & Total & 8 & & 31 & & 9 & & 48 & \\
\hline \multirow{5}{*}{$\begin{array}{l}\text { Pendi } \\
\text { dikan }\end{array}$} & SD & 0 & 0 & 5 & 71 & 2 & 29 & 7 & 100 \\
\hline & SMP & 0 & 0 & 13 & 72 & 5 & 28 & 18 & 100 \\
\hline & SMA & 7 & 32 & 13 & 59 & 2 & 9 & 22 & 100 \\
\hline & PT & 1 & 100 & 0 & 0 & 0 & 0 & 1 & 100 \\
\hline & Total & 8 & & 31 & & 9 & & 48 & \\
\hline \multirow{3}{*}{\multicolumn{2}{|c|}{$\begin{array}{l}\text { Karakteristik } \\
\text { Responden }\end{array}$}} & \multicolumn{6}{|c|}{ Tingkat Pengetahuan } & \multirow{2}{*}{\multicolumn{2}{|c|}{ Jumlah }} \\
\hline & & \multicolumn{2}{|c|}{ Baik } & \multicolumn{2}{|c|}{ Cukup } & \multicolumn{2}{|c|}{$\mathrm{Krg}$} & & \\
\hline & & $f$ & $\%$ & & $f$ & $\%$ & & $f$ & $\%$ \\
\hline \multirow{3}{*}{$\begin{array}{l}\text { Peker } \\
\text { jaan }\end{array}$} & IRT & 5 & 15 & 24 & 70 & 5 & 15 & 34 & 100 \\
\hline & $\begin{array}{l}\text { W.swa } \\
\text { sta }\end{array}$ & 3 & 21 & 7 & 50 & 4 & 29 & 14 & 100 \\
\hline & Total & 8 & & 31 & 9 & & & 48 & \\
\hline
\end{tabular}

Hasil pengumpulan data tingkat pengetahuan berdasarkan karakteristik umur pada 9 responden dalam kategori umur $<20$ tahun didapatkan hasil paling banyak dengan tingkat pengetahuan cukup yaitu 8 responden (89\%) dan paling sedikit dengan tingkat pengetahuan kurang yaitu 1 responden (11\%). Pada 38 responden dalam kategori umur 20-35 tahun didapatkan paling banyak dengan tingkat pengetahuan cukup yaitu 22 responden (58\%) dan paling sedikit dengan tingkat pengetahuan kurang yaitu 8 responden (21\%). Pada 1 responden dalam kategori umur >35 tahun didapatkan bahwa responden tersebut memiliki pengetahuan cukup (100\%).

Umur merupakan salah satu faktor yang memengaruhi pengetahuan seseorang. Semakin tua umur seseorang maka pengalamannya akan semakin banyak. Akan tetapi, pada umur tertentu bertambahnya proses perkembangan mental tidak secepat ketika berumur belasan tahun. Daya ingat seseorang salah satunya dipengaruhi oleh umur. Bertambahnya umur seseorang dapat berpengaruh pada pertambahan pengetahuan yang diperolehnya, akan tetapi pada umur tertentu atau menjelang usia lanjut kemampuan penerimaan suatu pengetahuan akan berkurang.

Dalam penelitian ini umur bukanlah faktor utama yang menentukan tingkat pengetahuan ibu hamil tentang pemanfaatan buku KIA. Hal ini ditunjukkan dari hasil penelitian bahwa tidak ada perbedaan tingkat pengetahuan pada sebagian besar ibu hamil dengan umur $<20$ tahun, 20-35 tahun, dan >35 tahun. 
Sebagian besar responden memiliki tingkat pengetahuan cukup.

Hasil analisis data berdasarkan karakteristik pendidikan didapatkan jumlah terbanyak pada ibu hamil dengan pendidikan terakhir SMA sebanyak 22 responden (46\%) dan paling sedikit pada ibu hamil dengan pendidikan terakhir perguruan tinggi sebanyak 1 responden (2\%). Pendidikan diperlukan untuk mendapat informasi sehingga dapat meningkatkan kualitas hidup. Pada umumnya semakin tinggi pendidikan maka seseorang akan semakin mudah menerima informasi. Pengetahuan dan pendidikan berkontribusi terhadap perubahan perilaku kesehatan. $^{7}$

Dalam penelitian ini terdapat banyak faktor yang memengaruhi tingkat pengetahuan ibu hamil tentang pemanfaatan buku KIA. Hal ini ditunjukkan dari hasil penelitian bahwa meskipun responden memiliki tingkat pendidikan lebih tinggi dari responden lain tetapi memiliki pengetahuan rendah, sementara responden dengan tingkat pendidikan rendah memiliki pengetahuan cukup. Hasil penelitian ini sesuai dengan penelitian yang dilakukan Zainiyah bahwa tingkat pendidikan bukan faktor utama yang menentukan tingkat pengetahuan ibu hamil tentang pemanfaatan buku KIA. ${ }^{8}$

Berdasarkan karakteristik pekerjaan pada 34 responden dengan pekerjaan ibu rumah tangga didapatkan hasil paling banyak memiliki pengetahuan cukup yaitu 24 responden (70\%) dan paling sedikit memiliki pengetahuan baik dan kurang yaitu masingmasing 5 responden (15\%). Pada 14 responden dengan pekerjaan wiraswasta didapatkan hasil paling banyak memiliki pengetahuan cukup yaitu 7 responden (50\%) dan paling sedikit memiliki pengetahuan baik yaitu 3 ibu hamil (21\%).

Hasil penelitian menunjukkan bahwa pekerjaan memengaruhi pengetahuan. Bekerja umumnya merupakan kegiatan yang menyita waktu. Lingkungan pekerjaan dapat menjadikan seseorang memperoleh pengalaman dan pengetahuan baik secara langsung maupun secara tidak langsung. ${ }^{9}$

Hasil penelitian menunjukkan bahwa pekerjaan tidak sepenuhnya memengaruhi tingkat pengetahuan ibu hamil tentang pemanfaatan buku KIA. Pekerjaan sebagai ibu rumah tangga tidak dapat menjamin ibu hamil memiliki banyak waktu luang untuk membaca buku KIA di rumah. Sehingga sebagian besar pengetahuan ibu hamil yang bekerja sebagai ibu rumah tangga dalam penelitian ini hanya dalam kategori cukup. Sementara pekerjaan sebagai wiraswasta tidak menjamin ibu hamil tidak memiliki waktu untuk membaca buku KIA.

\section{KESIMPULAN}

Berdasarkan hasil penelitian, karakteristik umur terbanyak pada kategori umur 20-35 tahun yaitu 38 responden (79\%), pendidikan terakhir SMA yaitu 22 responden (46\%) dan pekerjaan terbanyak pada ibu rumah tangga yaitu 31 responden (65\%). 
Tingkat pengetahuan ibu hamil tentang pemanfaatan buku Kesehatan Ibu dan Anak berdasarkan karakteristik umur menunjukkan dari 9 responden dengan usia <20 tahun terbanyak pada kategori cukup yaitu 8 responden (89\%), pada 38 responden dengan usia 20-35 tahun terbanyak pada kategori cukup yaitu 22 responden (58\%) dan pada 1 responden dengan usia $>35$ tahun pada kategori cukup (100\%). Pada 7 responden dengan pendidikan terakhir SD terbanyak pada kategori cukup yaitu 5 responden (71\%), pada 16 responden dengan pendidikan terakhir SMP terbanyak pada kategori cukup yaitu 12 responden (72\%), pada 22 responden dengan pendidikan terakhir SMA terbanyak pada kategori cukup yaitu 13 responden (59\%) dan pada 1 responden dengan pendidikan terakhir Perguruan Tinggi pada kategori baik (100\%). Pada 34 responden dengan pekerjaan sebagai ibu rumah tangga terbanyak pada kategori cukup yaitu 24 responden (70\%) dan pada 14 responden dengan pekerjaan wiraswasta terbanyak pada kategori cukup yaitu 7 responden (50\%).

Saran utamanya diberikan kepada bidan untuk meningkatkan pemanfaatan buku Kesehatan Ibu dan Anak sebagai alat komunikasi antara petugas kesehatan, ibu hamil, suami dan keluarga, melalui KIE yang berkualitas dalam pelayanan antenatal.

\section{KEPUSTAKAAN}

1. SDKI. Angka Kematian Ibu di Indonesia.
Jakarta. 2012.

2. Dinas Kesehatan Provinsi Jawa Tengah. Profil Dinas Kesehatan Provinsi Jawa Tengah. Jawa Tengah. 2012.

3. Dinas Kesehatan Kabupaten Magelang. Profil Dinas Kesehatan Kabupaten Magelang. Magelang. 2012.

4. Departemen Kesehatan Republik Indonesia. Petunjuk Teknis Penggunaan Buku KIA. Jakarta: Departemen Kesehatan RI dan JICA. 2010.

5. Dinas Kesehatan Kabupaten Magelang. Cakupan Pendistribusian Buku Kesehatan Ibu dan Anak di Kabupaten Magelang. Magelang. 2012.

6. Arikunto, S. Prosedur Penelitian Suatu Pendekatan Praktik. Jakarta: RinekaCipta. 2013.

7. Wawan, A dan Dewi. Teori \& Pengukuran Pengetahuan, Sikap dan Perilaku Manusia. Yogyakarta: Nuha Medika. 2012.

8. Zainiyah, Z. Gambaran Tingkat Pengetahuan lbu Hamil Tentang Pemanfaatan Buku KIA di BPS Musdalifah, Bangkalan. KTI. 2011.

9. Mubarak. Promosi Kesehatan. Yogyakarta: Graha IImu. 2007.

10. Departemen Kesehatan Republik Indonesia. Buku Kesehatan Ibu dan Anak. Jakarta: Departemen Kesehatan RI dan JICA. 2008.

11. Marmi. Asuhan Kebidanan Pada Masa Antenatal. Yogyakarta: Pustaka Pelajar. 2011. 
12. Notoatmodjo, S. Metodologi Penelitian Kesehatan. Jakarta: Rineka Cipta. 2012.

13. Prawirohardjo, S. IImu Kebidanan. Jakarta: Bina Pustaka. 2008.

14. Yongky. Asuhan Kehamilan, Persalinan, Neonatus Bayi dan Balita. Yogyakarta: Nuha Medika. 2012. 